\title{
Knockout of the Bcmo1 gene results in an inflammatory response in female lung, which is suppressed by dietary beta-carotene
}

\author{
Yvonne G. J. van Helden · Sandra G. Heil · Frederik J. van Schooten • \\ Evelien Kramer $\cdot$ Susanne Hessel $\cdot$ Jaume Amengual $\cdot$ Joan Ribot $\cdot$ \\ Katja Teerds • Adrian Wyss · Georg Lietz • M. Luisa Bonet · Johannes von Lintig • \\ Roger W. L. Godschalk · Jaap Keijer
}

Received: 4 December 2009/Revised: 22 January 2010/ Accepted: 11 February 2010/Published online: 6 April 2010

(C) The Author(s) 2010. This article is published with open access at Springerlink.com

\begin{abstract}
Beta-carotene 15,15'-monooxygenase 1 knockout $\left(\mathrm{Bcmol}^{-1-}\right)$ mice accumulate beta-carotene (BC) similarly to humans, whereas wild-type $\left(\mathrm{BCmol}^{+/+}\right)$mice efficiently cleave BC. Bcmol ${ }^{-/-}$mice are therefore suitable to investigate $\mathrm{BC}$-induced alterations in gene expression in lung, assessed by microarray analysis. $\mathrm{Bcmol}^{-1-}$ mice receiving control diet had increased expression of
\end{abstract}

Y. G. J. van Helden · S. G. Heil · K. Teerds · J. Keijer $(\bowtie)$

Department of Human and Animal Physiology,

Wageningen University, PO Box 338,

6700 AH Wageningen, The Netherlands

e-mail: Jaap.Keijer@wur.nl

Y. G. J. van Helden · F. J. van Schooten · R. W. L. Godschalk Department of Health Risk Analysis and Toxicology,

Research Institute NUTRIM, Maastricht University,

Maastricht, The Netherlands

Y. G. J. van Helden · S. G. Heil · E. Kramer

RIKILT-Institute of Food Safety, Wageningen, The Netherlands

S. Hessel

Institute of Biology I, University of Freiburg, Freiburg, Germany

J. Amengual · J. Ribot $\cdot$ M. L. Bonet

Laboratory of Molecular Biology, Nutrition and Biotechnology, University of the Balearic Islands (UIB) and CIBER de

Fisiopatología de la Obesidad y Nutrición (CIBERobn),

Palma de Mallorca, Spain

\author{
A. Wyss \\ R\&D Human Nutrition and Health, DSM Nutritional Products, \\ Kaiseraugst, Switzerland \\ G. Lietz \\ School of AFRD, Newcastle University, Newcastle, UK \\ J. von Lintig \\ Department of Pharmacology, School of Medicine, \\ Case Western Reserve University, Cleveland, OH, USA
}

inflammatory genes as compared to BC-supplemented $\mathrm{BCmol}^{-/-}$mice and $\mathrm{BCmol}^{+/+}$mice that received either control or BC-supplemented diets. Differential gene expression in $\mathrm{BCmol}^{-/-}$mice was confirmed by real-time quantitative PCR. Histochemical analysis indeed showed an increase in inflammatory cells in lungs of control $\mathrm{Bcmol}^{-/-}$ mice. Supported by metabolite and gene-expression data, we hypothesize that the increased inflammatory response is due to an altered BC metabolism, resulting in an increased vitamin A requirement in $\mathrm{BCmol}^{-1-}$ mice. This suggests that effects of BC may depend on inter-individual variations in $\mathrm{BC}$-metabolizing enzymes, such as the frequently occurring human polymorphisms in $\mathrm{BCMO1}$.

Keywords ATBC and CARET study - Beta-carotene 15,15'-monooxygenase 1 . Whole-mouse genome microarray gene expression - Inflammation .

Vitamin A deficiency $\cdot$ ADH7 $\cdot$ LRAT

\section{Introduction}

Beta-carotene (BC) is an orange-colored dietary compound present in various fruits and vegetables. BC is regarded as an active antioxidant and is thus able to diminish radical-induced macromolecular damage [1]. Because of this, a high intake of $\mathrm{BC}$ might be expected to be beneficial, and indeed epidemiological studies have shown that a high dietary intake of BC is associated with a lower risk for cardiovascular diseases and several types of cancer, including lung cancer [2,3]. Moreover, BC can be metabolized into vitamin $\mathrm{A}$, thereby preventing vitamin A deficiency. Vitamin A deficiency can result in a wide variety of clinical manifestations, ranging from night blindness, growth abnormalities, an increased 
susceptibility for infections, as well as an increased mortality due to infectious diseases $[4,5]$. In Western society, smokers are at risk for vitamin A deficiency in the lung $[6,7]$. Since dietary BC intake is able to prevent vitamin A deficiency and is associated with a decreased lung cancer risk, it was hypothesized that BC supplementation in smokers would be beneficial and would decrease lung cancer incidence. In contrast to this expectation, BC supplementation alone (ATBC study, [8]) or in combination with vitamin E (CARET study, [9]) resulted in an increased lung cancer risk in smokers and asbestos-exposed subjects [8, 9]. An increased lung cancer risk was predominantly observed in smokers and asbestos-exposed subjects and not in former or nonsmokers [10, 11]. Moreover, a 6-year follow-up of the CARET study revealed that females were more at risk for the development of lung cancer upon BC supplementation compared to male volunteers [12]. The underlying mechanisms are not precisely known, although several mechanisms have been suggested. Possibly, BC or BC metabolites can become pro-oxidants at high concentrations [13] or in combination with oxidative stress [14]. There is also evidence that BC supplementation can result in a changed regulation of the transcription factor retinoic acid receptor (RAR) [15]. However, the exact mechanism behind the possible adverse effect of a high BC intake is still poorly understood.

An important drawback in BC research is BC metabolism. First of all, BC metabolism in humans is highly variable [16, 17] and most of this variability can be attributed to differences in enzymatic activity of the betacarotene $15,15^{\prime}$-monooxygenase 1 enzyme (BCMO1). The $267 \mathrm{~A}>\mathrm{T}$ and $379 \mathrm{C}>\mathrm{T}$ polymorphisms in the $\mathrm{BCMO1}$ gene are common with variant allele frequencies of 42 and $24 \%$, respectively, in Caucasian population of the United Kingdom, and result in increased BC and decreased BC metabolite concentrations in plasma [18, 19]. Secondly, inter-species differences, especially in Bcmo1 activity, are the cause of the great differences in BC-metabolizing activity between humans and regularly used laboratory rodents. Rodents have a more active Bcmo1 enzyme variant than humans [20], and therefore $\mathrm{BC}$ supplementation to rodents results in a virtually complete conversion of $\mathrm{BC}$ and consequently in a high concentration of BC metabolites. Previously, a Bcmol knockout $\left(\mathrm{Bcmol}^{-/-}\right)$mouse was established and characterized, and BC supplementation to these $\mathrm{Bcmol}^{-/-}$ mice resulted in increased $\mathrm{BC}$ plasma concentrations and $\mathrm{BC}$ accumulation in mouse lung tissue [21]. This $\mathrm{Bcmol}^{-1-}$ mouse is therefore a unique model to investigate the effects of BC itself.

The aim of our study was to investigate $\mathrm{BC}$-induced gene-expression differences. Therefore, female $\mathrm{Bcmol}^{+/+}$ and $\mathrm{Bcmol}^{-1-}$ mice, unable to symmetrically cleave BC, were fed for 14 weeks with a vitamin A-sufficient diet $(1,500 \mathrm{IU} / \mathrm{kg}$ ) without (control) or with supplementation of $\mathrm{BC}(\mathrm{BC}, 150 \mathrm{mg} / \mathrm{kg}$ diet) and microarray analysis was performed (whole-mouse genome arrays) on lung copy RNA (cRNA). We specifically chose female animals because the effects of BC were more pronounced and longer-lasting in female volunteers of the CARET study [12]. Moreover, wild-type $\left(\mathrm{BCmol}^{+/+}\right)$mice were analyzed to distinguish $\mathrm{BC}$-induced effects from the effects due to the knockout of the Bcmol gene.

\section{Materials and methods}

Animals and treatment

Twelve female $(\mathrm{Fe}) \mathrm{B} 6129 \mathrm{SF} 1\left(\mathrm{Bcmol}^{+/+}\right)$and 12 female B6;129S-Bcmol ${ }^{\text {tmldnp }}\left(\right.$ Bcmol $\left.^{-1-}\right)$ mice, previously described by Hessel et al. [21] were used for the experiment. The mouse experiment was conducted in accordance with German animal protection laws by the guidelines of the local veterinary authorities. During the breeding and weaning periods of the mice, mothers were maintained on KLIBA 3430 chow containing 14,000 IU vitamin A/kg diet (Provima Kliba AG, Kaiseraugst, Switzerland). Fiveweek-old female $\mathrm{Bcmol}^{+/+}$and $\mathrm{Bcmol}^{-/-}$mice were caged in groups containing 2-4 siblings per group and were maintained under environmentally controlled conditions (temperature $24^{\circ} \mathrm{C}, 12 \mathrm{~h} / 12 \mathrm{~h}$ light-dark cycle). Mice had ad libitum access to feed and water. Basic feed consisted of the palletized diet D12450B (Research Diets Inc, USA) with a fat content of $10 \%$. The diet was modified to contain $1,500 \mathrm{IU}$ vitamin $\mathrm{A} / \mathrm{kg}$ of diet, which is a vitamin A-sufficient diet, and the control diet was supplemented with water-soluble vehicle beadlets (DSM Nutritional Products Ltd., Basel, Switzerland) containing DL-alpha-tocopherol and ascorbyl palmitate as stabilizers, as well as carriers such as gelatine, corn oil sucrose, and starch. The BC diet was supplemented with identical water-soluble beadlets containing 10\% BC (DSM Nutritional Products Ltd., Basel, Switzerland) to generate $150 \mathrm{mg} \mathrm{BC} / \mathrm{kg}$ diet. Beadlets were added by the manufacturer before low-temperature pelletting. Feed pellets were color-marked and stored at $4^{\circ} \mathrm{C}$ in the dark.

After 14 weeks of dietary intervention, six female $\mathrm{BCmol}^{+/+}$on the control diet $\left(\mathrm{BCmol}^{+/+} \mathrm{Co}\right)$, six female $\mathrm{BCmol}^{+/+}$on the $\mathrm{BC}$ diet $\left(\mathrm{Bcmol}^{+/+} \mathrm{BC}\right)$, three female $\mathrm{BCmol}^{-1-}$ on the control diet $\left(\mathrm{BCmol}^{-1-} \mathrm{Co}\right)$ and three female $\mathrm{BCmol}^{-1-}$ on the $\mathrm{BC}$ diet $\left(\mathrm{BCmol}^{-1-} \mathrm{BC}\right)$ were randomly sacrificed during three subsequent mornings. Blood was collected from the vena cava after isoflurane and ketamine anesthesia. Blood was coagulated for at least 
$20 \mathrm{~min}$ at room temperature, cooled to $4{ }^{\circ} \mathrm{C}$, and then centrifuged. Lung tissue was removed, rinsed in phosphate buffered saline (PBS) and snap-frozen in liquid nitrogen. The lung tissues were stored at $-80^{\circ} \mathrm{C}$. Due to an insufficient number of female $\mathrm{Bcmol}^{-1-}$ mice in the original breeding pool, female $\mathrm{BCmol}^{-/-}$mice were used that were born 2 weeks later from an identical experiment, treated identically with three mice on the control diet and three mice on the $\mathrm{BC}$ diet to generate $n=6$ per group, and sacrificed 2 weeks after the first group of mice.

HPLC separation of retinoids and carotenoids

Retinoids and carotenoids were extracted from lung tissues and plasma under dim red safety light $(\lambda \geq 600 \mathrm{~nm})$. Briefly, tissues (20-40 mg) were homogenized in $200 \mu \mathrm{l}$ of $2 \mathrm{M}$ hydroxylamine ( $\mathrm{pH}$ 6.8) and $200 \mu \mathrm{l}$ of methanol with a glass homogenizer. For determination of $\mathrm{BC}$ and retinol in serum, $180 \mu \mathrm{l}$ serum was added to $200 \mu \mathrm{l}$ methanol. Then $400 \mu \mathrm{l}$ acetone was added either to these plasma or tissue extracts. Extraction of carotenoids and retinoids was performed with petroleum ether. The extraction was repeated three times, and the collected organic phases were dried under nitrogen and redissolved in HPLC solvent (n-hexane/ethanol, 99.5:0.5). HPLC separation of carotenoids and retinoids and quantification of peak integrals was performed as previously described [22]. Solvents for HPLC and extraction were purchased in HPLC grade from Merck (Darmstadt, Germany).

Serum analysis of inflammation markers

Serum levels of the inflammatory cytokines; tumor necrosis factor alpha (TNF- $\alpha$ ), interleukin-6 (IL-6) and monocyte chemoattractant protein-1 (MCP-1) were measured using the mouse serum adipokine Lincoplex Kit (Linco Research, Nuclilab, Ede, The Netherlands). Sera were diluted four times in HPE buffer (Sanquin, Amsterdam, The Netherlands) and measured according to the manufacturer's protocol and as described before [23]. Cytokine levels were measured using the Bio-Plex system (Bio-Rad, Veenendaal, The Netherlands) and using BioPlex software (Bio-Rad). All individual samples were analyzed in duplicate and averaged. The detection limit of MCP-1 was $60 \mathrm{pg} / \mathrm{ml}$, of IL- 6 was $5 \mathrm{pg} / \mathrm{ml}$, and of TNF- $\alpha$ was $0.3 \mathrm{pg} / \mathrm{ml}$.

\section{Histology of the lung}

Small pieces of upper-right-lung tissue of two randomly selected animals per group were fixed by immersion in $0.1 \mathrm{M}$ sodium phosphate buffer containing $4 \%$ paraformaldehyde ( $\mathrm{pH} 7.4$ ) overnight at $4^{\circ} \mathrm{C}$, thereafter dehydrated, cleared, and then paraffin-embedded. Three $\mu \mathrm{m}$-thick sections were cut and stained with periodic acid schiff (PAS) and Mayer's hematoxylin for histological analysis.

\section{RNA isolation}

Left-lung lobes were homogenized in liquid nitrogen using a cooled mortar and pestle. Total RNA was isolated using TRIzol reagent (Invitrogen, Breda, The Netherlands) followed by purification using RNeasy columns (Qiagen, Venlo, The Netherlands) using the instructions of the manufacturer. RNA concentration and purity were measured using the Nanodrop system (IsoGen Life Science, Maarsen, The Netherlands). Approximately $30 \mu \mathrm{g}$ of total RNA was isolated with $A_{260} / A_{280}$ ratios above 2 and $A_{260} /$ $A_{230}$ ratios above 1.9 for all samples, indicating good RNA purity. RNA degradation was checked on the Experion automated electrophoresis system (Bio-Rad, Veenendaal, The Netherlands) using Experion StdSense chips (BioRad). Two samples did not meet RNA quality $\left(\mathrm{Bcmol}^{+/+}\right.$ mice, one on $\mathrm{BC}$ diet and one on control diet) and were omitted from the experiment.

\section{Microarray hybridization procedure}

The $4 \times 44 \mathrm{k}$ Agilent whole-mouse genome microarrays (G4122F, Agilent Technologies, Inc., Santa Clara, CA) were used. Preparation of the sample and the microarray hybridization were carried out according to the manufacturer's protocol with a few exceptions as described previously [23, 24]. In brief, cDNA was synthesized from $1 \mu \mathrm{g}$ lung RNA using the Agilent Low-RNA Input Fluorescent Linear Amplification Kit for each animal without addition of spikes. Thereafter, samples were split into two equal amounts, to synthesize Cyanine 3-CTP (Cy3) and Cyanine 5-CTP (Cy5) labeled cRNA using half the amounts per dye as indicated by the manufacturer (Agilent Technologies). Labeled cRNA was purified using RNeasy columns (Qiagen). Yield, $A_{260} / A_{280}$ ratio and Cy3 or Cy5 activity were examined for every sample using the nanodrop. All samples met the criteria of a cRNA yield higher than $825 \mathrm{ng}$ and a specific activity of at least 8.0 pmol Cy3 or Cy5. Then, 1,200 ng of every Cy3-labeled cRNA sample was pooled and used as a common reference pool. Individual 825-ng Cy5-labeled cRNA and 825-ng pooled Cy3-labeled cRNA were fragmented in $1 \times$ fragmentation and $1 \times$ blocking agent (Agilent Technologies) at $60^{\circ} \mathrm{C}$ for $30 \mathrm{~min}$ and thereafter mixed with GEx Hybridization Buffer HI-RPM (Agilent Technologies) and hybridized in a $1: 1$ ratio at $65^{\circ} \mathrm{C}$ for $17 \mathrm{~h}$ in the Agilent Microarray Hybridization Chamber rotating at $4 \mathrm{rpm}$. After hybridization, slides were washed according to the wash protocol with Stabilization and Drying solution (Agilent 
Technologies). Arrays were scanned with an Agilent scanner with 10 and $100 \%$ laser-power intensities (Agilent Technologies).

Data analyses of microarray results

Signal intensities for each spot were quantified using Feature Extraction 9.1 (Agilent Technologies). Median density values and background values of each spot were extracted for both the experimental samples (Cy5) and the reference samples $(\mathrm{Cy} 3)$.

Quality control for every microarray was performed visually by using 'Quality' control graphs from 'Feature' extraction and M-A plots and boxplots, which were made using limmaGUI in R (Bioconductor) [25]. Data were imported into GeneMaths XT 2.0 (Applied Maths, SintMartens-Latem, Belgium). Spots with a Cy5 and Cy3 signal twice above background were selected and logtransformed. The Cy5 signal was normalized against the Cy3 intensity as described before [26]. Supervised principal component analysis and heat mapping were performed using GeneMaths XT. Volcano plots were made using GraphPad Prism 5.0. Pathway analysis was performed using MetaCore (GeneGo), GO overrepresentation analysis (ErmineJ) [27] and literature mining.

Analysis of mRNA expression by real-time quantitative PCR (Q-PCR)

Real-time quantitative PCR (Q-PCR) was performed on individual samples ( $n=6$ per group) as previously described [28] to validate the microarray data. One microgram of RNA of all individual samples was used for cDNA synthesis using the iScript cDNA synthesis kit (BioRad). Q-PCR reactions were performed with iQ SYBR Green Supermix (Bio-Rad) using the MyIQ single-color real-time PCR detection system (Bio-Rad). Each reaction $(25 \mu \mathrm{l})$ contained $12.5 \mu \mathrm{l}$ iQ SYBR green supermix, $1 \mu \mathrm{l}$ forward primer $(10 \mu \mathrm{M}), 1 \mu \mathrm{l}$ reverse primer $(10 \mu \mathrm{M})$, $8.5 \mu \mathrm{l}$ RNase-free water and $2 \mu \mathrm{l}$ diluted cDNA. The following cycles were performed: $1 \times 3 \mathrm{~min}$ at $95^{\circ} \mathrm{C}, 40$ amplification cycles $\left(40 \times 15 \mathrm{~s} \quad 95^{\circ} \mathrm{C}, 45 \mathrm{~s}\right.$ optimal annealing temperature, which was followed by $1 \times 1 \mathrm{~min}$ $95^{\circ} \mathrm{C}$ and $1 \times 1 \min 65^{\circ} \mathrm{C}$ and a melting curve was prepared $\left(60 \times 10 \mathrm{~s} 65^{\circ} \mathrm{C}\right.$ with an increase of $0.5^{\circ} \mathrm{C}$ per $\left.10 \mathrm{~s}\right)$. A negative control without cDNA template and a negative control without reverse transcriptase $(-\mathrm{RT})$ were taken along with every assay. Data were normalized against the reference genes syntaxin $5 a$ (Stx5a) and ring finger protein 130 (Rnf130), which were chosen based on stable geneexpression levels between the mice on the microarray. Primers were designed using Beacon designer 7.00 (Premier Biosoft International, Palo Alto, CA). The following primer sequences were used; reference gene Stx5a formward 5'-TTAAAGAACAGGAGGAAACGATTCAGAG$3^{\prime}$ and reverse 5'-CAGGCAAGGAAGACCACAAAGA TG-3' (PCR at $60.0^{\circ} \mathrm{C}$ ), reference gene Rnfl30 forward $5^{\prime}$-ACAGGAACCAGCGTCGTCTTG- $3^{\prime}$ and reverse $5^{\prime}$-ACCCGAACAACATCATTCTGCTTATAG-3' (PCR at $60.0^{\circ} \mathrm{C}$ ), interferon, alpha-inducible protein 27 (Ifi27) forward $5^{\prime}$-GCTGCTACCAGGAGGACTCAAC- $3^{\prime}$ and reverse $5^{\prime}$ - TGCTGATTGGAGTGTGGCTACC- $3^{\prime}$ (PCR at $59.2^{\circ} \mathrm{C}$ ), tripartite motif protein 12 (Trim12) forward $5^{\prime}$-GGAGAACATCATAGAACGGAGTCATAC- $3^{\prime}$ and reverse $5^{\prime}$ - GGAAGACCCCTAGTAGCGATGAG-3' (PCR at $58.3^{\circ} \mathrm{C}$ ), ISG15 ubiquitin-like modifier (Isg15) forward $5^{\prime}$-TGCAGCAATGGCCTGGGAC- $3^{\prime}$ and reverse $5^{\prime}$-GCGCTGCTGGAAAGCCG- $3^{\prime}$ (PCR at $58.3^{\circ} \mathrm{C}$ ), interferon-induced protein 44 (Ifi44) forward $5^{\prime}$ - AGAC TTGATAAAACATGGCATTCTGC- $3^{\prime}$ and reverse $5^{\prime}$ CATGGAATGCCTCCAGCTTGG- $3^{\prime}$ (PCR at $58.3^{\circ} \mathrm{C}$ ). A standard curve for all genes, including reference genes, was generated using serial dilutions of a pooled sample (cDNA from all reactions of the groups analyzed). mRNA levels were determined using the $\Delta \Delta \mathrm{CT}$ method (IQ5 software version 2.0; Bio-Rad). Analysis of individual samples was performed in duplicate.

Statistical analysis

Fold changes for both microarray gene expression and Q-PCR gene expression were calculated using mean log signal intensities. $P$ values for differential expressions were calculated between two groups using two-tailed Student's $t$ test statistics on log intensity values. Changes were considered statistically different at $p<0.05$. Effects of diet and genotype on concentrations of $\mathrm{BC}$, retinol, and retinyl esters in lung and serum were analyzed using $2 \times 2$ factorial univariate ANOVA (SPSS version 15.0) and considered statistically significant when $p<0.05$. Correlations and differences in correlations between $\mathrm{BC}$ concentration and $\mathrm{BC}$ metabolite concentrations in lung were tested (SPSS) and considered significant when $p<0.05$.

\section{Results}

BC supplementation results in an increased BC concentration in lungs, particularly in $\mathrm{Bcmol}^{-/-}$mice

BC supplementation resulted in elevated BC levels in serum and lung tissue of all mice $(p<0.05)$, but to a higher extent in $\mathrm{BCmol}^{-1-}$ mice (Fig. 1a, b, p<0.05). Retinol serum levels were not significantly different between the groups (Fig. 1c). Retinol and retinyl ester 
Fig. $1 \mathrm{BC}$ and $\mathrm{BC}$ metabolite concentration in lungs of female $\mathrm{Bcmol}^{-/-}$and $\mathrm{Bcmol}^{+/+}$mice. Beta-carotene (BC) $(\mathbf{a}, \mathbf{b})$ and retinol (c, d) concentrations in serum and in lung tissue, respectively, and retinyl ester concentrations in lung tissue (e) of female $\mathrm{Bcmol}^{+/+}$mice and $\mathrm{BCmol}^{-1-}$ mice fed a control diet (white bars) or a BC-supplemented diet (black bars). Data are expressed as mean \pm SEM, significance was tested using ANOVA and considered significant at $p<0.05$. $D$ effect of diet, $G$ effect of genotype, $D \times G$ interaction between diet and genotype. Student's $t$ test was performed between the $\mathrm{BC}$ and control diet and considered significant at $p<0.05$. $* p<0.05, * * p<0.01$ and $* * * p<0.001$

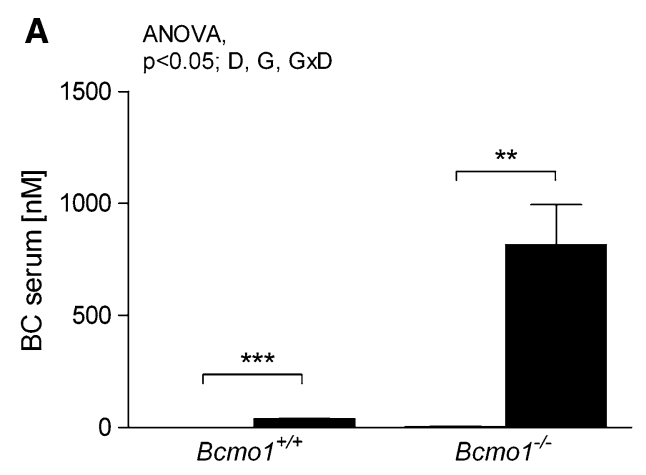

B $\quad \begin{aligned} & \text { ANOVA } \\ & \mathrm{p}<0.05 ; D, G, D \times G\end{aligned}$

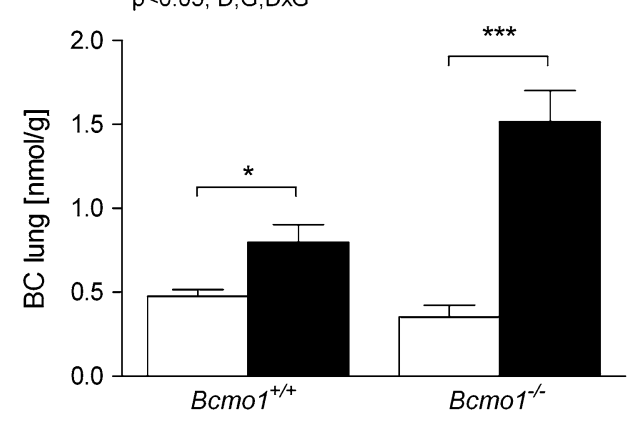

C

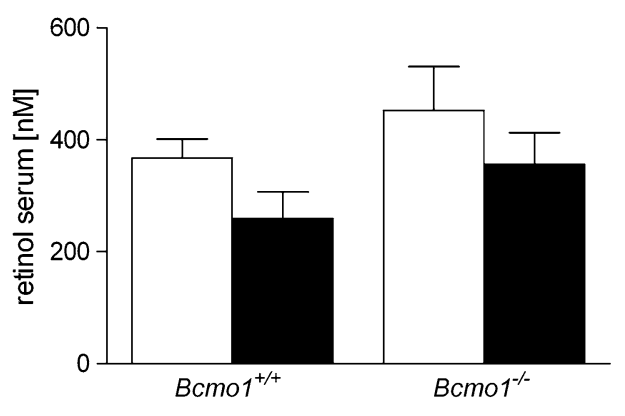

D $\quad \begin{aligned} & \text { ANOVA } \\ & \mathrm{p}<0.05 ; \mathrm{D}\end{aligned}$

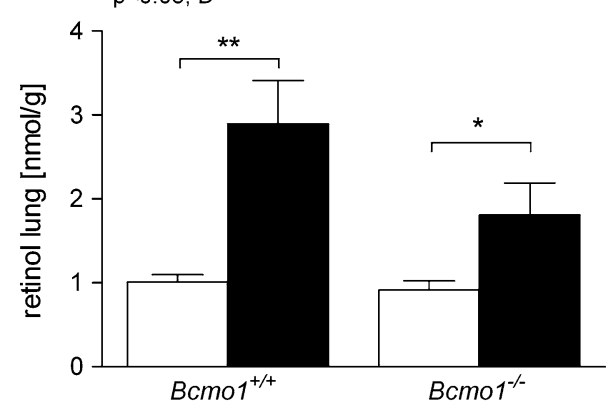

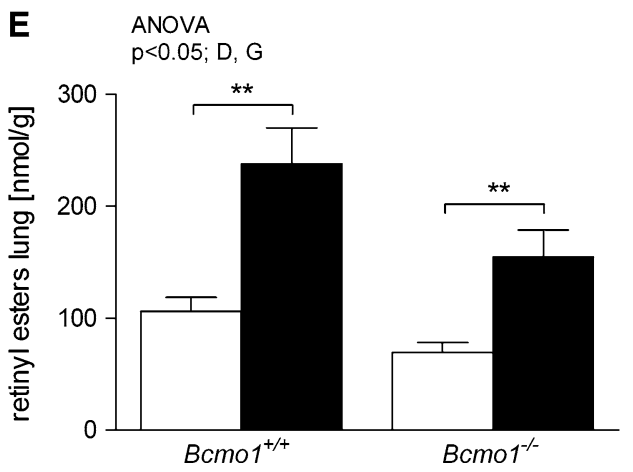

concentrations in lung were increased in all mice upon BC supplementation $(p<0.05)$, and as expected, to a higher extend in $\mathrm{BCmol}^{+/+}$(Fig. 1d, e).

$\mathrm{BC}$ supplementation to $\mathrm{Bcmol}^{-1-}$ mice restores differential gene expression to levels as observed in $\mathrm{BCmol}^{+/+}$mice

To investigate the effects of $\mathrm{BC}$ on lung gene expression, microarray analysis was performed on cRNA of all mice. Of the 43,379 spots (number of spots on array minus control spots), 31,128 had a signal twice above background and were regarded as positive spots and included in the analysis. Supervised principal component analysis (SPCA) showed that animals could be discriminated according to their Bcmol genotype and diet (Fig. 2a). BC supplementation resulted in 651 and 1,522 differentially expressed genes $(p<0.05)$ in the $\mathrm{Bcmol}^{+/+}$and $\mathrm{Bcmol}^{-1-}$ mice, respectively. Of these $\mathrm{BC}$-regulated genes, 32 were commonly regulated in $\mathrm{Bcmol}^{+/+}$and $\mathrm{Bcmol}^{-/-}$mice and thus regulated independent of genotype.

We were interested in the effects resulting from $\mathrm{BC}$ accumulation in lung tissue. Since $B C$ levels in lung tissue were higher in $\mathrm{Bcmol}^{-/-}$mice than in $\mathrm{Bcmol}^{+/+}$mice and, correspondingly, more genes were regulated in this group after $\mathrm{BC}$ supplementation, we further focused on effects of $\mathrm{BC}$ in $\mathrm{Bcmol}^{-1-}$ mice. Of the 1,522 BC-regulated genes in the $\mathrm{Bcmol}^{-/-}$mice, 121 had an absolute fold-change (FC) $>1.5$-fold, with mainly down-regulated genes (Fig. 2b). We continued with these 121 BC-regulated genes and investigated whether these genes were regulated due to an effect of $\mathrm{BC}$ treatment in $\mathrm{Bcmol}^{-/-}$mice or due to an effect in the $\mathrm{BCmol}^{-1-}$ control mice. Therefore, we evaluated gene expression of these 121 genes in all four groups; $\mathrm{BCmol}^{+/+}$control mice, $\mathrm{Bcmol}^{+/+}$mice with supplementation of $\mathrm{BC}, \mathrm{Bcmol}^{-/-}$control mice and $\mathrm{Bcmol}^{-/-}$mice with BC supplementation. The absolute expression of each of the 121 genes was set on one for the $\mathrm{Bcmol}^{+/+}$control 

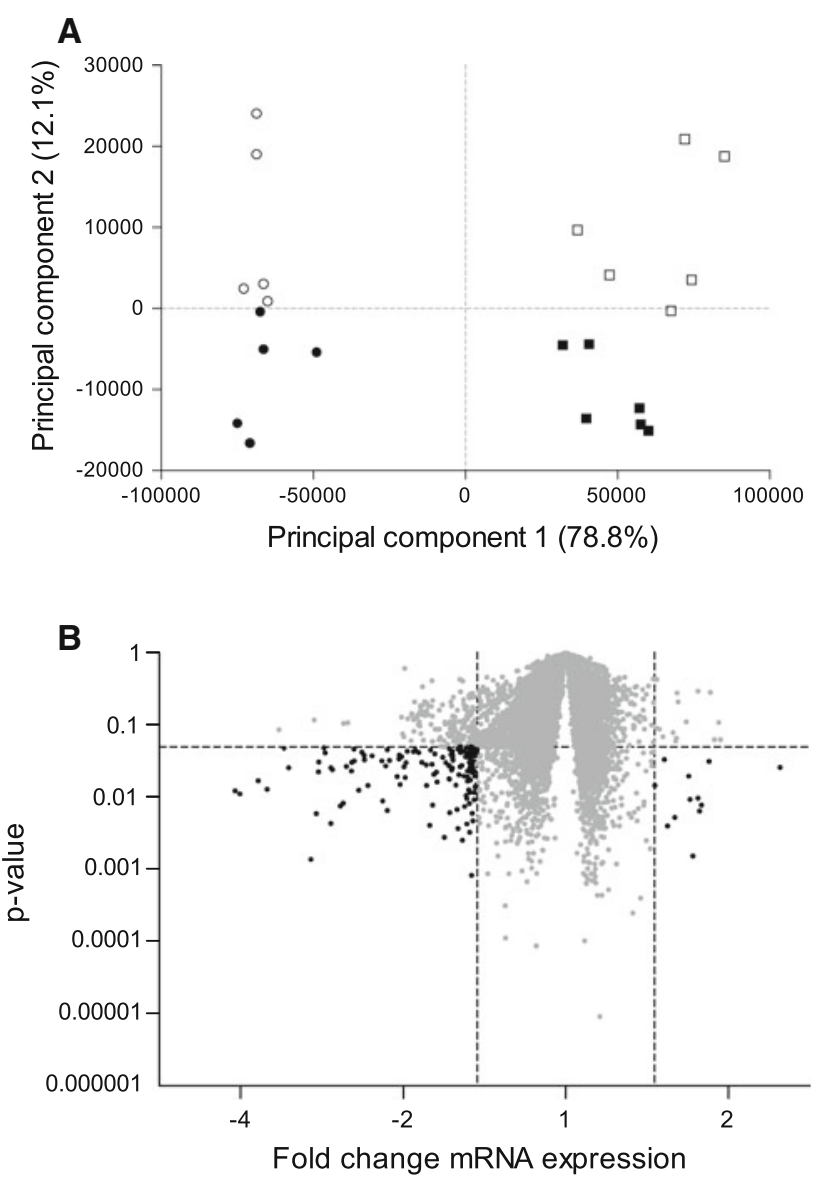

Fig. 2 Supervised principal component analysis and volcano plot of the microarray data. a Supervised principal component analysis (SPCA) of the four groups; Bcmol ${ }^{+/+}$control mice (open circles), Bcmol $^{+/+} \mathrm{BC}$ mice (closed circles), Bcmol ${ }^{-/-}$control mice (open squares), and $\mathrm{Bcmol}^{-1-} \mathrm{BC}$ mice (closed squares). $\mathrm{Bcmol}^{+/+}$mice are separated from $\mathrm{Bcmol}^{-/-}$mice ( $x$-axis) and mice on control diet are separated from mice on the $\mathrm{BC}$ diet ( $y$-axis). b Volcano plot of the effect of $\mathrm{BC}$ supplementation on gene expression in $\mathrm{Bcmol}^{-1-}$ mice, showing the fold-change on the $x$-axis and the corresponding Student's $t$ test $p$ value on the $y$-axis. In black are all the genes with a $p$ value $<0.05$ and an absolute fold-change $>1.5$. Trim12 with a FC of 8.75 and $p<0.05$ is outside the limits of this figure

mice. Cluster analysis of the expression of these genes showed that the $\mathrm{BCmol}^{-1-}$ control mice differed most in gene expression compared to the other three groups (Fig. 3a). The expression of these genes was compared to the expression in the $\mathrm{Bcmol}^{+/+}$control mice and revealed that the average absolute fold-change was significantly different in the $\mathrm{BCmol}^{-1-}$ control mice compared to the $\mathrm{BCmol}^{+/+}$control mice $(p<0.001)$, while there was no difference between the average expression of these 121 genes between the $\mathrm{BC}$-supplemented $\mathrm{BCmol}^{-/-}$mice or $\mathrm{BCmol}^{+/+}$mice and the $\mathrm{BCmol}^{+/+}$control mice (Fig. 3b).
A
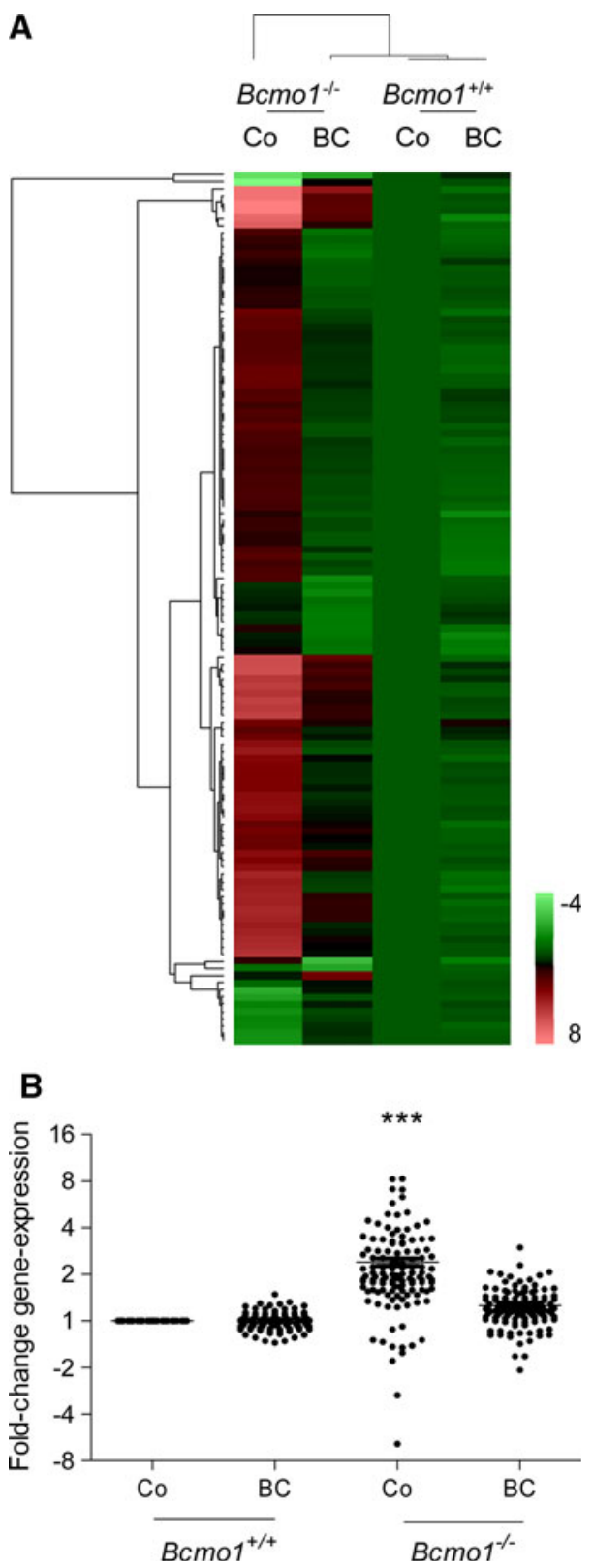

Fig. 3 Relative expression of genes regulated by $\mathrm{BC}$ in $\mathrm{Bcmol}^{-/-}$ mice in all groups. a Hierarchical clustering of all experimental groups based on the expression of all genes regulated by $\mathrm{BC}$ in the $\mathrm{BCmol}^{-1-}$ mice with an absolute $\mathrm{FC}>1.5$ and $p<0.05$. The expression of every gene is represented relative to the expression in $\mathrm{BCmol}^{+/+}$control mice, which was set to 1.0 . Genes and groups were clustered using Euclidean distance (linear scaled) UPGMA. b Graph representing the expression level of all genes regulated by $\mathrm{BC}$ in the $\mathrm{BCmol}^{-1-}$ mice with an absolute $\mathrm{FC}>1.5$ and $p<0.05$, in all groups. The expression of every gene is represented relative to the expression in $\mathrm{BCmol}^{+/+}$control mice, which was set to 1.0. The absolute expression was significantly higher $(p<0.001)$ in $\mathrm{Bcmol}^{-1-}$ control mice compared to mice in the other groups. There was no significant difference in expression level between the other groups. $* * * p<0.001$ 
These data indicate that there was mainly an effect of the knockout of the Bcmol gene in the mice fed the control diet, which was returned to normal levels as observed in the $\mathrm{BCmol}^{+/+}$mice by $\mathrm{BC}$ supplementation.

\section{Confirmation of array results by Q-PCR}

Real-time quantitative PCR (Q-PCR) was used to validate microarray results. Genes with the highest upregulation in $\mathrm{BCmol}^{-1-}$ control mice compared to all other groups: interferon-induced protein 44 (Ifi44) (Fig. 4a), and interferon-induced protein 27 (Ifi27) (Fig. 4b); downregulation in $\mathrm{Bcmol}^{-1-}$ control mice: tripartite motif-containing 12 (Trim12) (Fig. 4c), and previously demonstrated retinoic acid responsiveness: ISG15 ubiquitin-like modifier (Isg15) [29] (Fig. 4d) were selected for quantification. Microarray results were confirmed by Q-PCR, resulting in a virtual identical and significant downregulation of Ifi44, ifi27, ISG15, and an upregulation of Trim12 in BC-supplemented $\mathrm{BCmol}^{-/-}$mice compared to $\mathrm{BCmol}^{-/-}$control mice in both microarray and Q-PCR analysis.

Gene expression and histology showed an increase in inflammatory responses in lungs of $\mathrm{Bcmol}^{-1-}$ control mice

We further classified the 121 genes that were regulated in $\mathrm{BCmol}^{-/-}$control mice with an absolute FC $>1.5$ compared to BC-supplemented $\mathrm{BCmol}^{-/-}$mice into general biological process categories (Table 1). The main affected biological process category was the immune response and in particular direct interferon-induced gene response (Fig. 5). ErmineJ overrepresentation analysis and MetaCore analysis also showed that there was an overrepresentation of the inflammatory response in $\mathrm{Bcmol}^{-/-}$control mice compared to $\mathrm{BC}$-supplemented $\mathrm{BCmol}^{-/}$mice using the whole dataset (ErmineJ; GO:0006954, Inflammatory response, $p<10^{-7}$, MetaCore; several maps belonging to the cell process immune response, $p<2 \times 10^{-4}$ ).

Since most of the genes induced in $\mathrm{BCmol}^{-1-}$ mice on the control diet were involved in inflammatory responses, we investigated whether the mice had an increased concentration of the inflammation-related cytokines: tumor necrosis factor (TNF- $\alpha$ ), interleukin-6 (IL-6) and monocyte chemoattractant protein-1 (MCP-1). Serum concentrations of all three markers were below the detection limit (data not shown) while pulmonary infections usually would result in detectable serum concentrations of these markers [30].

We had additional material of two animals per group available for morphological analysis. Paraffin-embedded sections were stained with hematoxylin and PAS and then analyzed. Histology showed an overall healthy lung structure in all animals of the groups; $\mathrm{BCmol}^{+/+}$control mice, $\mathrm{Bcmol}^{+/+}$receiving $\mathrm{BC}$ supplementation and $\mathrm{BCmol}^{-/-}$receiving BC supplementation (Fig. $6 \mathrm{a}, \mathrm{b}, \mathrm{e}$ ). The overall lung histology of the $\mathrm{Bcmol}^{-/-}$control mice was however different from the other groups due to a general increase in the number of inflammatory cells in the lung and occasionally larger inflamed areas (Fig. 6d, e) resembling previously described lung histology upon vitamin A deficiency in rats [31].
Fig. 4 Confirmation of microarray results by real-time quantitative PCR (Q-PCR). The expression of the genes a Ifi44, b Ifi27, c Trim12 and d Isg15 in $\mathrm{BCmol}^{-1-}$ mice on a control diet and mice supplemented with $\mathrm{BC}$ as analyzed with microarray (left) and as analyzed by Q-PCR (right) using stable reference genes Stx5a and Rnf130. Data represent the average \pm SEM with the average expression of every gene set at 1.0 of mice fed the control diet. ${ }^{*} p<0.05$ using Student's $t$ test on the logtransformed data
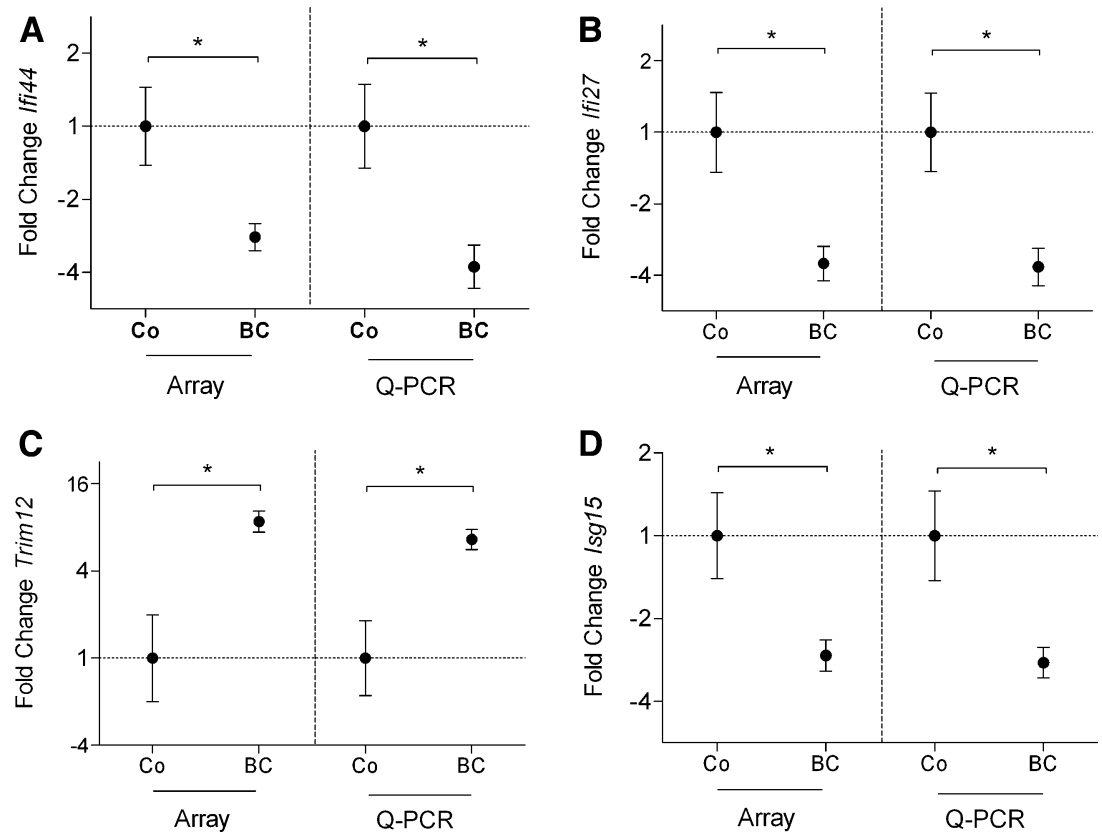


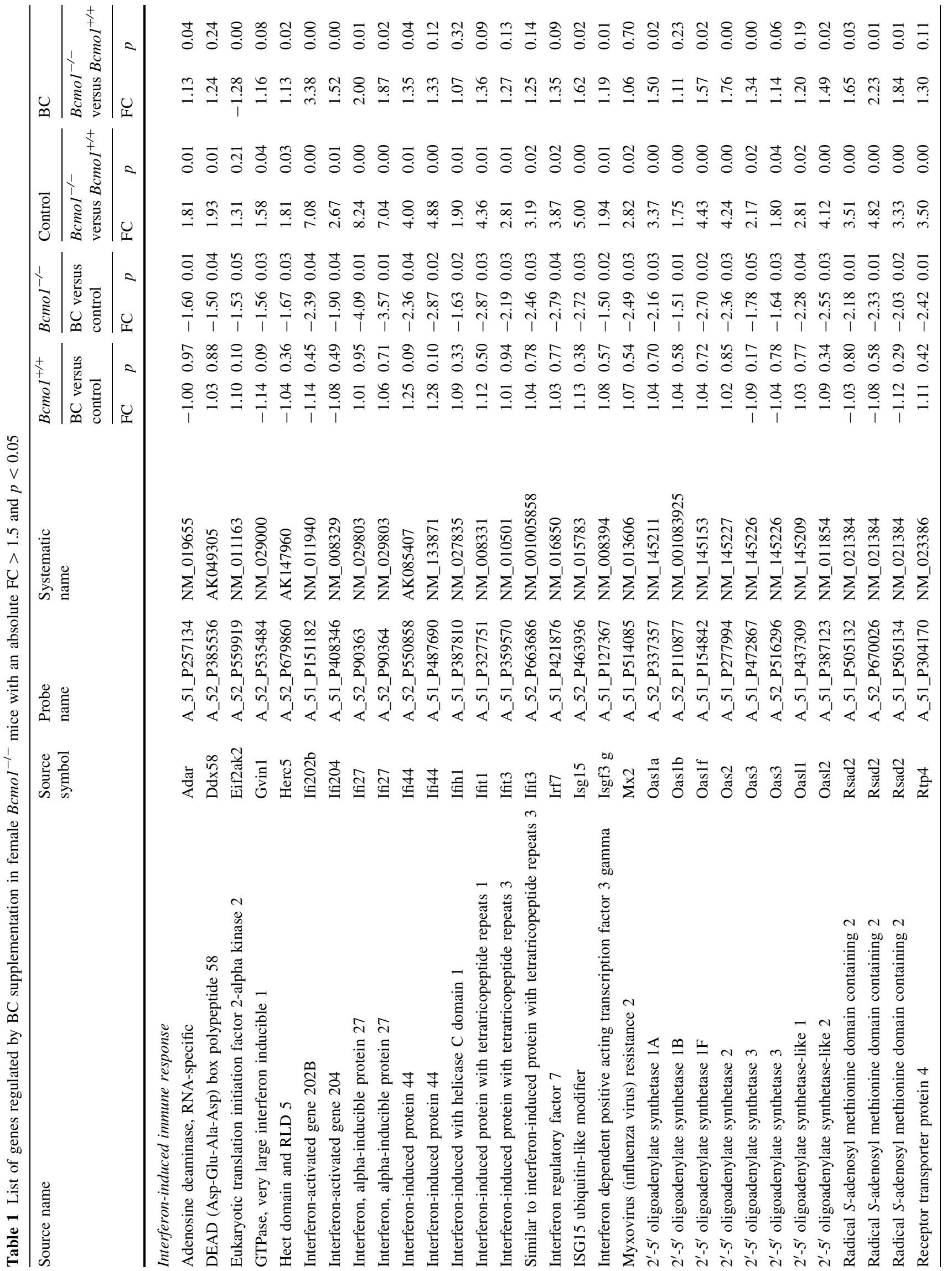




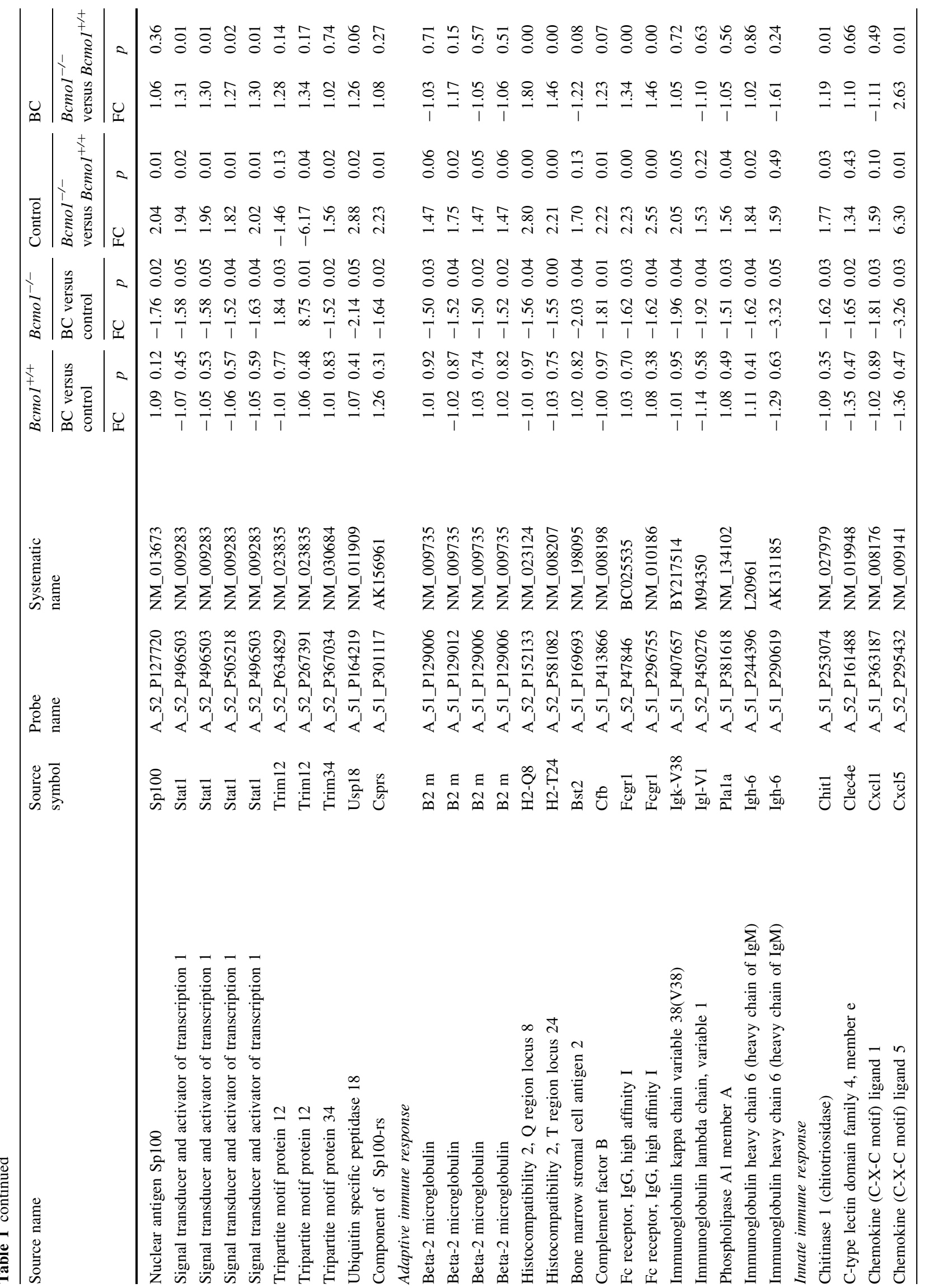




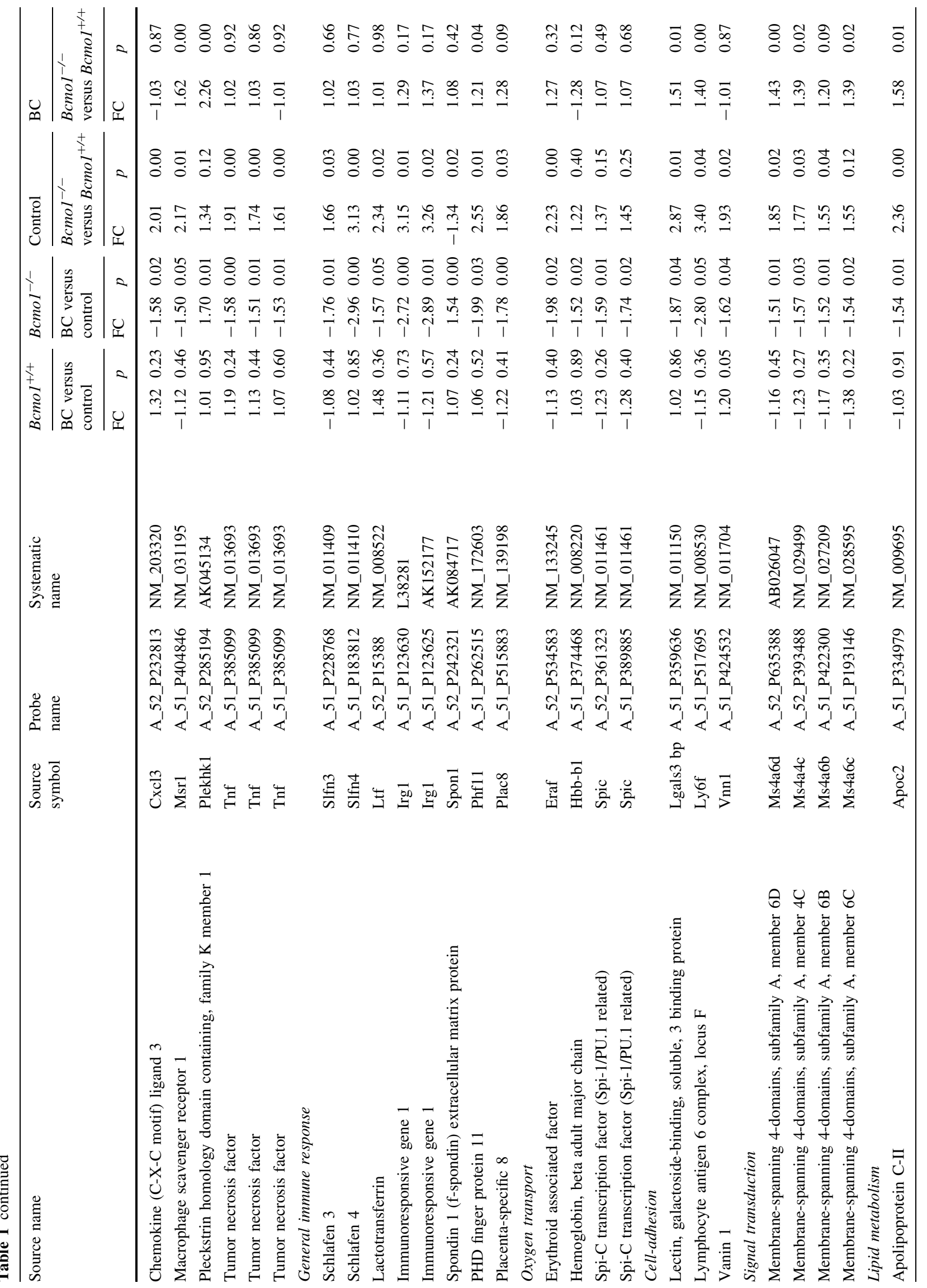




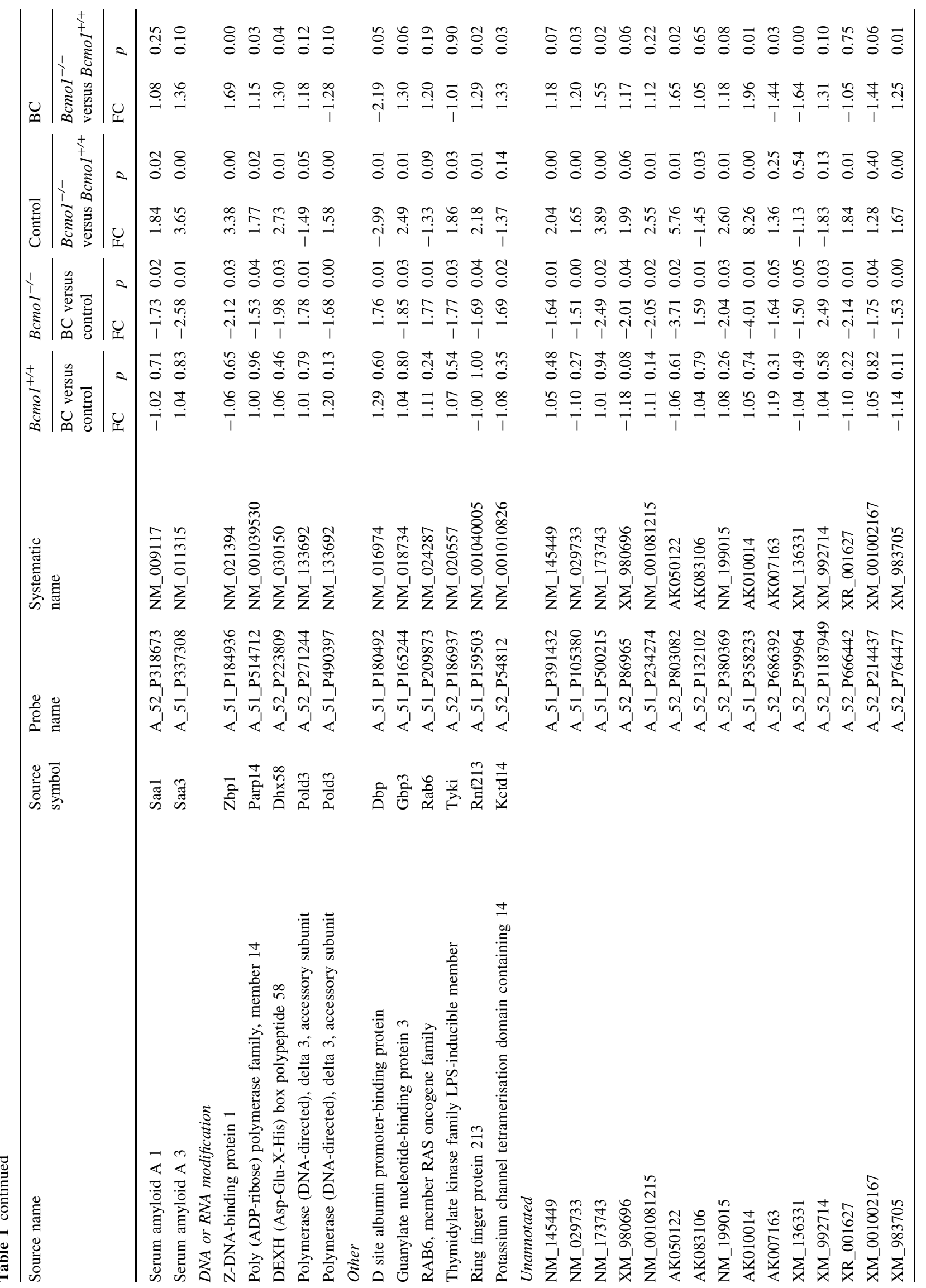




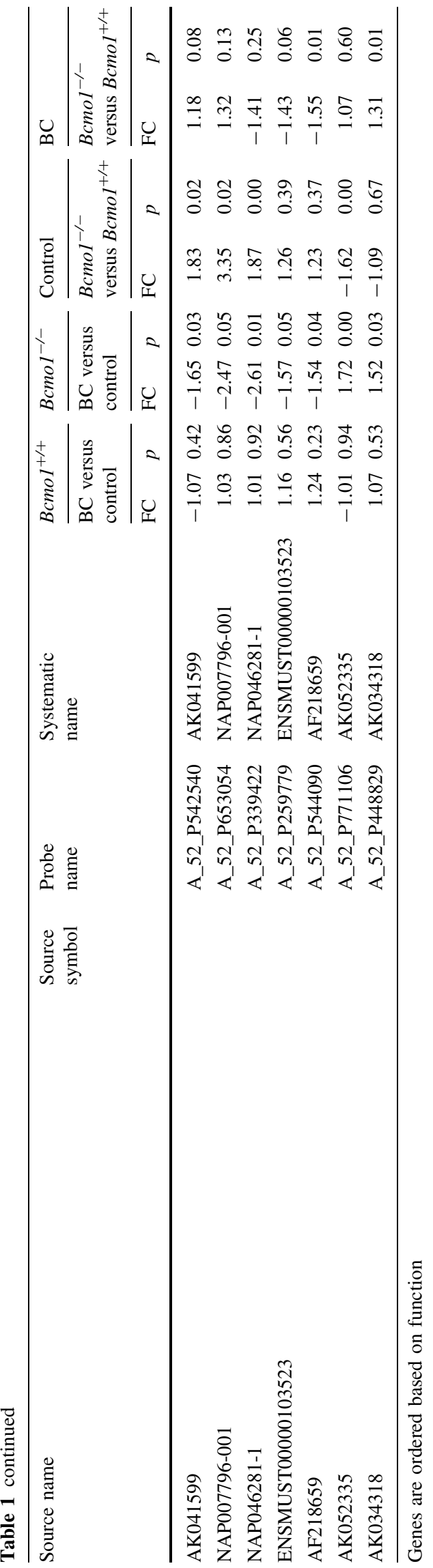

Expression of genes involved in BC metabolism are shifted towards an increased retinyl ester storage in $\mathrm{Bcmol}^{-/-}$mice

To further investigate whether a lack of $\mathrm{BC}$ or $\mathrm{BC}$ metabolites could explain the transcriptional and histological increased inflammatory response in the $\mathrm{BCmol}^{-/-}$ control mice, we investigated changes in downstream BC metabolism. First, we evaluated correlations between BC, retinol and retinyl ester concentrations in mouse lung. There was a significant positive correlation between retinyl ester and $\mathrm{BC}$ concentrations in lung tissue of $\mathrm{Bcmol}^{+/+}$ mice $(R=0.90, p<0.001)$ (Fig. 7a) with a much lower slope in the $\mathrm{Bcmol}^{-1-}$ mice $(R=0.87, p<0.001)$. There was no significant correlation between retinol and BC concentrations in lung tissue of both $\mathrm{BCmol}^{+/+}$as well as in $\mathrm{Bcmol}^{-1-}$ mice $(R=0.46, p=0.13$ and $R=0.52$, $p=0.10$ ) (Fig. 7b).

Additionally, the expression of genes involved in downstream BC metabolism and retinoic acid catabolism in the lungs was analyzed. Four genes involved in BC metabolism were differentially expressed in $\mathrm{Bcmol}^{-1-}$ mice compared to the $\mathrm{Bcmol}^{+/+}$mice (Table 2) with lecithin-retinol acyltransferase (Lrat) and alcohol dehydrogenase 7 class IV (Adh7) having the highest fold-change. The expression of Lrat, involved in the esterification of retinol into retinyl esters to store retinol [32], was 2.6 and 3.2 times up-regulated in $\mathrm{Bcmol}^{-1-}$ mice on the control and BC-supplemented diet, respectively, as compared to the $\mathrm{Bcmol}^{+/+}$control mice. Moreover, Adh7, the enzyme with the highest affinity and the highest conversion rate in the metabolism of retinol into retinal [33] was 2.7 times lower expressed in the $\mathrm{BCmol}^{-1-}$ mice on a control diet as compared to the $\mathrm{Bcmol}^{+/+}$control mice. BC supplementation of $\mathrm{Bcmol}^{-1-}$ mice partly restored this decreased $A d h 7$ expression.

\section{Discussion}

In this study we investigated transcriptional pathways that are regulated by $\mathrm{BC}$ in vivo in the lung to obtain insight into the possible mechanisms underlying previously found adverse effects of BC supplementation. For this purpose, we used a $\mathrm{BCmol}^{-1-}$ mouse model that is known to accumulate $\mathrm{BC}$ in serum and lung, as well as $\mathrm{Bcmol}^{+/+}$ mice that have increased $\mathrm{BC}$ metabolite concentrations upon BC supplementation. Lung gene expression was explored using whole-genome microarrays and revealed that mainly genes involved in inflammation were up-regulated in $\mathrm{BCmol}^{-1-}$ control mice. Similarly, histological analysis revealed an increased infiltration of inflammatory cells in $\mathrm{BCmol}^{-/-}$control mice. BC supplementation of 
Fig. 5 Biological processes affected in $\mathrm{BCmol}^{-/-}$control mice. Graph representing the number of genes differentially expressed in $\mathrm{Bcmol}^{-/}$control mice versus $\mathrm{BCmol}^{-1-} \mathrm{BC}$ supplemented mice. $p<0.05$ and absolute fold change $>1.5$ per biological processes category
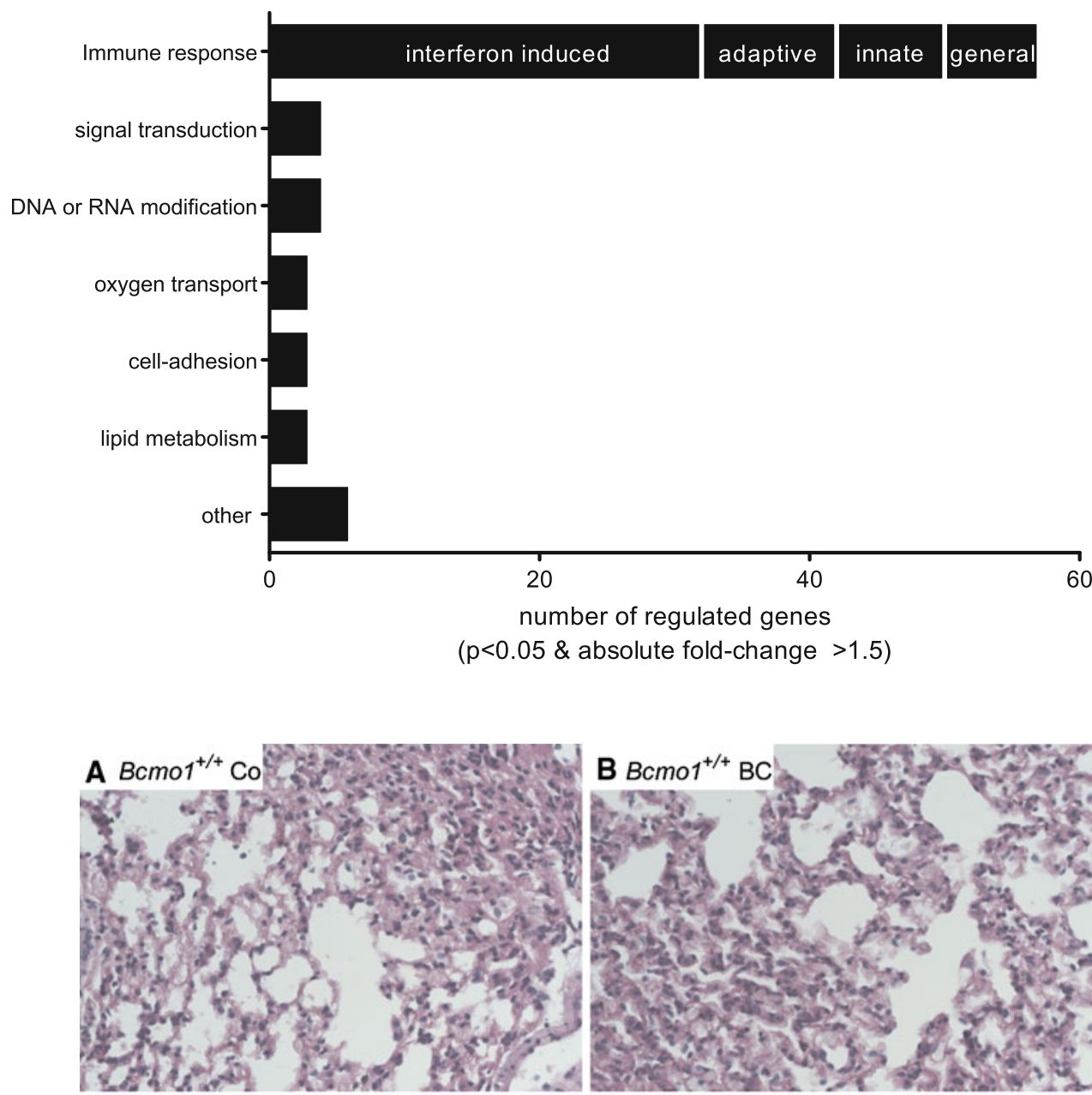

Fig. 6 Histological analysis of lung tissue. Representative sections (right upper lobe) of the lung of $\mathrm{Bcmol}^{+/+}$mice $(\mathbf{a}, \mathbf{b})$ and $\mathrm{Bcmol}^{-1-}$ mice $(\mathbf{c}-\mathbf{e})$ on a control diet $(\mathbf{a}, \mathbf{c}, \mathbf{d})$ or a BC-enriched diet $(\mathbf{b}, \mathbf{e})$. The lungs of $\mathrm{BCmol}^{-1-}$ mice receiving the control diet $(\mathbf{c}, \mathbf{d})$ had a different appearance compared to the lungs of the other groups, with an increase in inflammatory cells and occasionally some inflamed area's (d). Magnification: $40 \times$
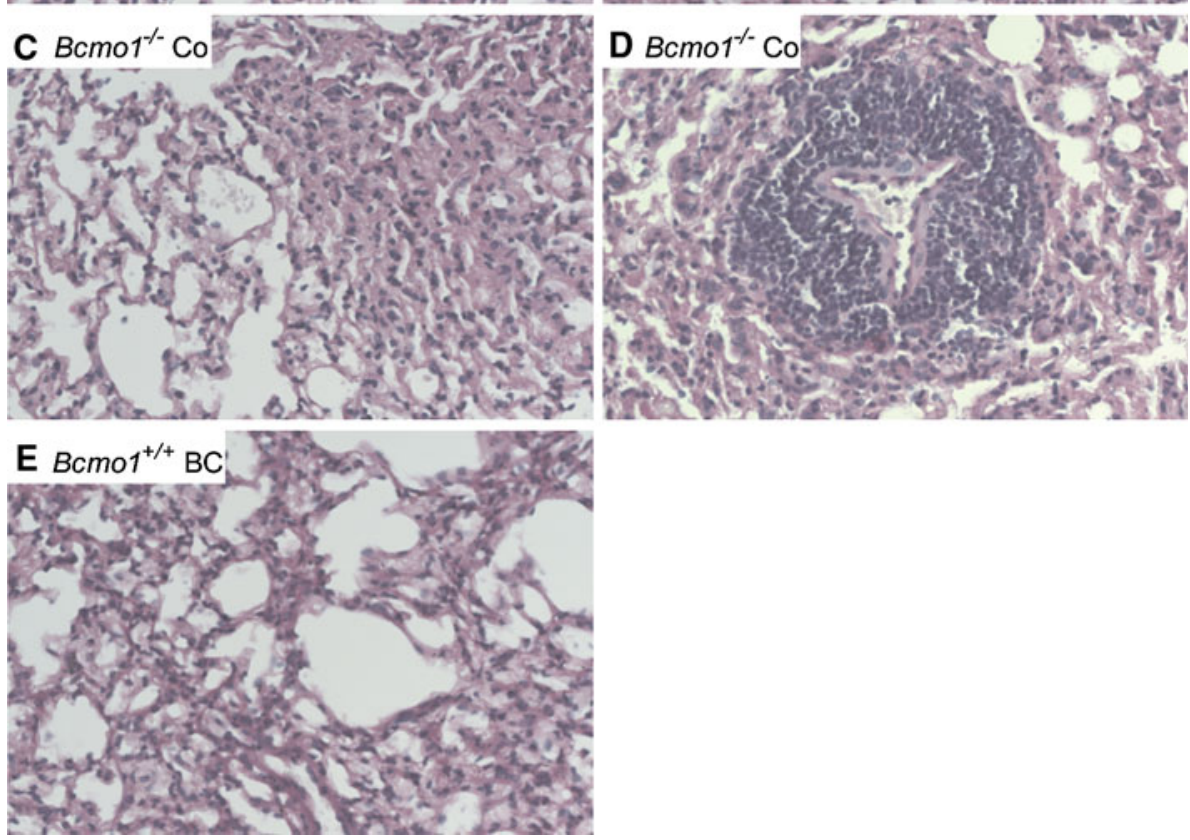

$\mathrm{Bcmol}^{-/-}$mice restored inflammatory gene expression and decreased the infiltration of inflammatory cells to levels as observed in $\mathrm{Bcmol}^{+/+}$control mice. An increased inflammatory response in the lungs has previously been observed upon vitamin A deficiency [34] and since BC supplementation could reverse the increase in 


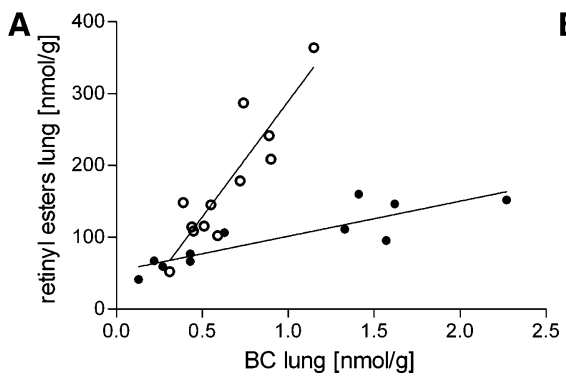

Fig. 7 Correlation of $\mathrm{BC}$ and $\mathrm{BC}$ metabolite concentrations in lung. Correlation of a $\mathrm{BC}$ concentration and retinyl ester concentration $\left(\right.$ Bcmol $\left.^{+/+}: R=0.90, p<0.001 ; B_{c m o l}{ }^{-1-}: R=0.87, p<0.001\right)$

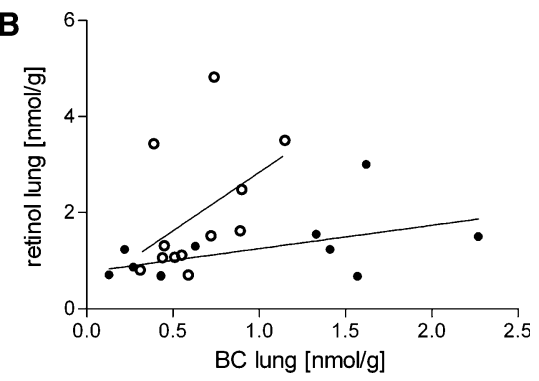

and $\mathbf{b} \mathrm{BC}$ concentration and retinol concentration $\left(\mathrm{Bcmol}^{+/+}\right.$: $\left.R=0.46, p=0.13 ; B_{c m o l^{-I}}: R=0.52, p=0.10\right)$ in lungs of $\mathrm{BCmoI}^{+/+}$mice (open circles) and $\mathrm{Bcmol}^{-{ }^{--}}$mice (closed circles)

Table 2 Genes involved in BC metabolism and retinoic acid catabolism, which are significantly regulated by the knockout of Bcmol

\begin{tabular}{|c|c|c|c|c|c|}
\hline \multirow[t]{2}{*}{ Systematic name } & \multirow[t]{2}{*}{ Source symbol } & \multicolumn{2}{|c|}{ Bcmol $^{+/+}$} & \multicolumn{2}{|c|}{ Bcmol $^{-1-}$} \\
\hline & & Co & $\mathrm{BC}$ & $\mathrm{Co}$ & $\mathrm{BC}$ \\
\hline Aldehyde dehydrogenase family 1 , subfamily A2 & Aldh1a2 & $1 \mathrm{a}$ & $-1.03 \mathrm{a}$ & $1.25 \mathrm{~b}$ & $1.20 \mathrm{~b}$ \\
\hline Aldehyde dehydrogenase family 1 , subfamily A3 & Aldh1a3 & 1a & $-1.25 b$ & $-1.43 \mathrm{c}$ & $-1.41 \mathrm{c}$ \\
\hline Aldehyde dehydrogenase 2 , mitochondrial & Aldh2 & $1 \mathrm{a}$ & $1.05 \mathrm{a}$ & $-1.18 \mathrm{~b}$ & $-1.01 \mathrm{a}$ \\
\hline Lecithin-retinol acyltransferase (phosphatidylcholine-retinol-O-acyltransferase) & Lrat & $1 \mathrm{a}$ & $1.58 \mathrm{~b}$ & $2.58 \mathrm{c}$ & $3.15 \mathrm{c}$ \\
\hline Alcohol dehydrogenase 7 (class IV), mu or sigma polypeptide & Adh7 & $1 \mathrm{a}$ & $-1.14 \mathrm{a}$ & $-2.67 b$ & $-2.16 \mathrm{c}$ \\
\hline
\end{tabular}

Different letters indicate significant differences (Student's $t$ test, $p<0.05$ )

inflammatory cells and inflammation-related gene expression, we hypothesize that these effects are due to increased dietary vitamin A requirement in $\mathrm{Bcmol}^{-1-}$ mice compared to $\mathrm{BCmol}^{+/+}$mice. An explanation for this increased vitamin $A$ requirement could lie in the altered downstream $\mathrm{BC}$ and vitamin $\mathrm{A}$ metabolism in $\mathrm{BCmol}^{-/-}$mice, resulting in a less efficient conversion of vitamin $\mathrm{A}$ into the bioactive form of vitamin A; retinoic acid. BC supplementation was able to restore these requirements despite the knockout of Bcmol.

We observed an increase in inflammatory cells in lung tissue and an increase in the expression of genes involved in inflammation in $\mathrm{Bcmol}^{-1-}$ control mice, which was restored by $\mathrm{BC}$ supplementation to levels observed in $\mathrm{Bcmol}^{+/+}$mice. An effect of BC itself on the inflammatory response has not been reported, whereas vitamin A deficiency has been reported to increase inflammation in rats [31,34]. Moreover, vitamin A supplementation in vitamin A-deficient populations reduced the number and severity of infections and decreased the infection-induced mortality rate [5]. Since vitamin A levels were approximately similar in lungs of $\mathrm{BCmol}^{-1-}$ mice fed with a control diet and $\mathrm{Bcmol}^{+/+}$mice, the increased inflammatory response likely involves the bioactive vitamin A metabolite retinoic acid. Retinoic acid is able to bind to the transcriptional active retinoic acid receptor (RAR) or to the retinoid $\mathrm{X}$ receptor (RXR), thereby modulating transcriptional responses. Indeed, effects on the inflammatory response have been shown to be regulated through the transcription factor retinoic acid receptor (RAR) [35, 36]. For example, Th1/Th2/Th17 balance, which is involved in adaptive immune response and important in the onset of autoimmune diseases, asthma, and allergic diseases, has been attributed to RAR activity. Interestingly, interferon-stimulated genes, which were predominant in our study, can also be RAR-regulated [37, 38]. Retinoic acid can be present in two isomers; all-trans retinoic acid (atRA) and 9-cis retinoic acid (9cRA), which have different transcriptional activities. Both isomers are able to bind to RAR, while only 9cRA can bind to RXR. Since effects on immunological function have mainly been attributed to RAR functioning, a shift in the balance of atRA and 9cRA is very unlikely to explain our results. We explain the increase in the inflammatory response in lungs of $\mathrm{BCmol}^{-1-}$ mice by a more general reduction in available retinoic acid in $\mathrm{BCmol}^{-/-}$control mice due to altered gene expression of downstream BC-metabolizing enzymes. The gene expression of Alcohol dehydrogenase 7 (class IV Adh7), a key enzyme in the conversion of vitamin A into retinal and an important step before the formation of biologically active retinoic acid [39], was 2.7-fold down-regulated in $\mathrm{BCmol}^{-/-}$mice compared to the $\mathrm{BCmol}^{+/+}$mice on the control diet. Indeed, Adh7 activity has previously been shown to be inversely associated with the degree of 
inflammation in the human gastric mucosa [40]. Additionally, an interaction between vitamin A concentration and $A d h 7$ expression was previously reported: a vitamin A-deficient diet led to a decreased fetal survival in Adh7 knockout mice compared to wild-type mice, but not on a vitamin A-sufficient diet [33, 41]. The 2.6-fold increase in lecithin-retinol-O-acyltransferase (Lrat) in $\mathrm{Bcmol}^{-/-}$mice was also striking. Lrat is the main enzyme [32] for conversion of retinol to retinylesters, a form in which vitamin A can be stored, indicating that vitamin $\mathrm{A}$ is rather esterified and stored in $\mathrm{Bcmol}^{-/-}$lungs. Taken together, these findings suggest that an increased inflammatory response in control $\mathrm{Bcmol}^{-1-}$ mice may be due to decreased retinoic acid production. BC supplementation prevents these effects in the $\mathrm{Bcmol}^{-/-}$mice, possibly because BC can substitute for retinoic acid production in a pathway dependent on beta-carotene dioxygenase 2 (Bdo2), an enzyme with the ability to asymmetrically cleave $\mathrm{BC}$, thereby generating $\beta$-apocarotenals and $\beta$-ionone [42], which can subsequently be further metabolized into retinoic acid [43]. Altogether, the altered gene expression of key enzymes for vitamin A metabolism may result in a changed dietary vitamin A requirement in $\mathrm{Bcmol}^{-/-}$mice, which changes the vitamin A-sufficient control diet for $\mathrm{Bcmol}^{+/+}$mice, into a mildly vitamin A-deficient diet for the $\mathrm{Bcmol}^{-1-}$ mice.

We demonstrated an altered BC metabolism in the $\mathrm{BCmol}^{-/-}$mice, which resulted, as intended, in an increased $\mathrm{BC}$ accumulation in lung and serum of the $\mathrm{BCmol}^{-/-}$mice. We also observed some differences in the gene expression of downstream BC-metabolizing enzymes. This changed metabolism might be important in understanding and investigating the physiological effects of $\mathrm{BC}$ in lung functioning, especially since there are large interhuman variations in BCMO1 activity due to polymorphisms in this gene. There were some interesting, unexpected changes in $\mathrm{BC}$ metabolite levels upon $\mathrm{BC}$ supplementation in $\mathrm{Bcmol}^{-/-}$mice. First of all, there was an increase in retinol in lung upon BC supplementation in $\mathrm{BCmol}^{-1-}$ mice. This increase in retinol is unlikely to be originating from metabolized BC. As far we know, only Bdo2 can serve as a partial alternative to Bcmo1 in $\mathrm{BC}$ metabolism. Bdo2 asymmetrically cleaves BC, thereby generating an increase in apocarotenals and ultimately into retinoic acid, which can be degraded by members of the Cytochrome P450 (CYP) family and in particular CYP26 [44, 45]. Retinol is probably not an intermediate in this alternative BC metabolism pathway. An increased retinol absorption in the lung, in combination with the (non-significant) decrease in retinol in plasma could theoretically clarify this observation. However, stimulated by retinoic acid 6 (Stra6), which is identified as a receptor for the blood retinol carrier; retinol-binding protein ( $\mathrm{Rbp}$ ) [46], was not significantly differentially expressed on the microarrays between the BC-supplemented and control diet-fed mice. A changed RBP-retinol complex has been associated with an increased delivery of retinol to different tissues [46, 47] and might possibly explain our retinol plasma and lung tissue concentrations. A second never reported interesting observation herein regarding $\mathrm{BC}$ metabolites in lung tissue was the tighter correlation of $\mathrm{BC}$ with retinyl esters than with retinol in lung tissue of Bcmol $^{+/+}$mice. This implies that BC accumulation tightly regulates the retinyl ester pool. Lung tissue has relatively high retinyl ester pools [48]. The main role for retinyl esters in the lung is to ensure direct retinol delivery when there is an increased retinol demand in the lung [49], especially during fetal development. We found a significant 6.5 -fold decrease in slope in the correlation of lung $\mathrm{BC}$ with retinyl esters in $\mathrm{BCmol}^{-/-}$mice compared to the Bcmol $^{+/+}$mice, which implies decreased conversion efficiency in the $\mathrm{Bcmol}^{-1-}$ mice. This decreased efficiency was also found in people containing two snp's in the BCMO1 gene, resulting in a decreased BCMO1 activity and a four-fold decreased conversion efficiency of $\mathrm{BC}$ as measured as the triglyceride-rich lipoprotein retinyl palmitate:BC ratio [18]. The surprising findings in $\mathrm{BC}$ metabolites in $\mathrm{Bcmol}^{+/+}$and $\mathrm{Bcmol}^{-/-}$mice and the understanding of these differences are especially important in understanding the effects of BC in humans, in particular since downstream BC metabolism is different between mice and humans, and also between humans.

Since we find inflammatory gene expression to be increased, the question may be raised whether there was an unintended infection present solely in the $\mathrm{Bcmol}^{-1-}$ control mice. There are some reasons to believe that this was not the case. First, we examined plasma levels of the cytokines; MCP-1, TNF- $\alpha$ and IL-6, which are highly increased and detectable upon infection [50]. These levels were below the limit of detection, which is representative for an uninfected state. In addition, the $\mathrm{Bcmol}^{-1-}$ mice both on a control diet and on a BC-supplemented diet were divided over two independent experiments. The significant up-regulation of the inflammatory response in the $\mathrm{BCmol}^{-1-}$ control mice was similar in both experimental periods, making infection an unlikely explanation. Moreover, an increased inflammatory response in the lungs is often seen during vitamin A deficiency. An altered downstream $\mathrm{BC}$ metabolism in $\mathrm{Bcmol}^{-/-}$mice, and thereby a higher vitamin A requirement in $\mathrm{Bcmol}^{-/-}$mice is therefore a likely explanation.

We initiated this study to identify the possible pathways explaining possible harmful effects of $\mathrm{BC}$. Therefore we used $\mathrm{Bcmol}^{-1-}$ mice, which are able to accumulate $\mathrm{BC}$ similar to humans. In this study, BC supplementation was beneficial in $\mathrm{Bcmol}^{-1-}$ mice, since $\mathrm{BC}$ supplementation reduced the inflammatory response in these mice and 
generated a gene-expression pattern more similar to $\mathrm{BCmol}^{+/+}$mice, as has been shown by cluster analysis. Although $\mathrm{BC}$ was beneficial in this model, these data also demonstrate that $\mathrm{BC}$ was able to influence the inflammatory response in the lungs. The harmful effects of $\mathrm{BC}$ have only been reported in smokers and asbestos-exposed subjects (ATBC, CARET). An important difference between smokers and asbestos-exposed subjects on one hand and non-smokers on the other, is that smoking causes an inflammatory response in the lungs, which is shown to be involved in the onset and progression of carcinogenesis [51-54]. Since we find differences in downstream BC-metabolizing enzymes, possible differences in these enzymes in smokers might give a clue in understanding the adverse effects of BC in smokers. Microarray analysis of small airway epithelium of smokers has revealed that several downstream BC metabolizing enzymes are indeed differentially expressed. Aldehyde dehydrogenase family 1 , subfamily A3 (ALDH1A3) was five-fold up-regulated and $A D H 7$ was six-fold up-regulated in smokers compared to non-smokers [55]. This paper implies that a proper retinoic acid synthesis is indispensable for correct functioning of the immune system. It would be of interest to investigate whether polymorphisms in BC-metabolizing enzymes in subjects of the ATBC and CARET study alter the lung cancer risk in smokers upon BC supplementation. Future studies using $\mathrm{Bcmol}^{-/-}$mice as well as $\mathrm{BCmol}^{+/+}$mice in combination with $\mathrm{BC}$ and smoke or inflammation induction are necessary to further investigate and explain exact mechanisms. Since the $\mathrm{BCmol}^{-/-}$mice seem to have a higher dietary need for vitamin A, this concentration should be increased to avoid effects of vitamin A deficiency.

All together, our results demonstrate that $\mathrm{BCmol}^{-1-}$ mice on a control diet had an increased inflammation in their lungs, which was decreased to levels as observed in $\mathrm{Bcmol}^{+/+}$mice upon BC supplementation. We hypothesize that this was due to an increased vitamin A requirement in $\mathrm{BCmol}^{-1-}$ due to impaired retinoic acid synthesis. Since the $\mathrm{Bcmol}^{-1-}$ control mice were mildly vitamin A-deficient, this study was unable to elucidate BC accumulation-regulated gene expression. Nevertheless, these results might be important for the human population since individuals with polymorphisms in the $\mathrm{BCMO1}$ gene, with a high population frequency, may also have a higher risk for vitamin A deficiency, which is still a relatively frequently occurring state in developing countries as well as in certain groups of the Western society.

Acknowledgments Yvonne van Helden was supported by a grant from NUTRIM/VLAG. This work is part of the research effort of the carotenoid focus team of the European Nutrigenomics Organization (Network of Excellence, EU Contract FOOD-CT-2004-506360) and has been sponsored in part by NuGO. We thank Sophie Alders for her contribution to the histological analysis. Jaap Keijer is a member of Mitofood (COST FA0602). CIBERobn is an initiative of the ISCIII (Spanish government). Adrian Wyss is employed by DSM neutraceuticals and facilitated the use of $\mathrm{BCmol}^{-1-}$ mice, BC beadlets, and helped in design of the study. None of the other authors declares any commercial interest. The study results and conclusions were derived independently of any commercial party (in particular DSM Nutritional Products) and were not amended.

Open Access This article is distributed under the terms of the Creative Commons Attribution Noncommercial License which permits any noncommercial use, distribution, and reproduction in any medium, provided the original author(s) and source are credited.

\section{References}

1. Ziegler RG (1991) Vegetables, fruits, and carotenoids and the risk of cancer. Am J Clin Nutr 53:251S-259S

2. van Poppel G (1996) Epidemiological evidence for beta-carotene in prevention of cancer and cardiovascular disease. Eur J Clin Nutr 50(Suppl 3):S57-S61

3. Ziegler RG (1989) A review of epidemiologic evidence that carotenoids reduce the risk of cancer. J Nutr 119:116-122

4. Sommer A (2008) Vitamin A deficiency and clinical disease: an historical overview. J Nutr 138:1835-1839

5. Glasziou PP, Mackerras DE (1993) Vitamin A supplementation in infectious diseases: a meta-analysis. BMJ 306:366-370

6. Edes TE, Gysbers DS (1993) Carcinogen-induced tissue vitamin A depletion. Potential protective advantages of beta-carotene. Ann N Y Acad Sci 686:11-203 discussion 211-2

7. Northrop-Clewes CA, Thurnham DI (2007) Monitoring micronutrients in cigarette smokers. Clin Chim Acta 377:14-38

8. ATBC Cancer Prevention Study Group (1994) The alphatocopherol, beta-carotene lung cancer prevention study: design, methods, participant characteristics, and compliance. The ATBC Cancer Prevention Study Group. Ann Epidemiol 4:1-10

9. Omenn GS, Goodman GE, Thornquist MD, Balmes J, Cullen MR, Glass A, Keogh JP, Meyskens FL Jr, Valanis B, Williams JH Jr, Barnhart S, Hammar S (1996) Effects of a combination of beta carotene and vitamin A on lung cancer and cardiovascular disease. N Engl J Med 334:1150-1155

10. Hennekens CH, Buring JE, Manson JE, Stampfer M, Rosner B, Cook NR, Belanger C, LaMotte F, Gaziano JM, Ridker PM, Willett W, Peto R (1996) Lack of effect of long-term supplementation with beta carotene on the incidence of malignant neoplasms and cardiovascular disease. N Engl J Med 334:11451149

11. Omenn GS, Goodman GE, Thornquist MD, Balmes J, Cullen MR, Glass A, Keogh JP, Meyskens FL Jr, Valanis B, Williams JH Jr, Barnhart S, Cherniack MG, Brodkin CA, Hammar S (1996) Risk factors for lung cancer and for intervention effects in CARET, the Beta-Carotene and Retinol Efficacy Trial. J Natl Cancer Inst 88:1550-1559

12. Goodman GE, Thornquist MD, Balmes J, Cullen MR, Meyskens FL Jr, Omenn GS, Valanis B, Williams JH Jr (2004) The BetaCarotene and Retinol Efficacy Trial: incidence of lung cancer and cardiovascular disease mortality during 6-year follow-up after stopping beta-carotene and retinol supplements. J Natl Cancer Inst 96:1743-1750

13. Palozza P (1998) Prooxidant actions of carotenoids in biologic systems. Nutr Rev 56:257-265

14. van Helden YG, Keijer J, Knaapen AM, Heil SG, Briede JJ, van Schooten FJ, Godschalk RW (2009) Beta-carotene metabolites 
enhance inflammation-induced oxidative DNA damage in lung epithelial cells. Free Radic Biol Med 46:299-304

15. Russell RM (2004) The enigma of beta-carotene in carcinogenesis: what can be learned from animal studies. J Nutr 134:262S-268S

16. Hickenbottom SJ, Follett JR, Lin Y, Dueker SR, Burri BJ, Neidlinger TR, Clifford AJ (2002) Variability in conversion of beta-carotene to vitamin $\mathrm{A}$ in men as measured by using a double-tracer study design. Am J Clin Nutr 75:900-907

17. Lin Y, Dueker SR, Burri BJ, Neidlinger TR, Clifford AJ (2000) Variability of the conversion of beta-carotene to vitamin $\mathrm{A}$ in women measured by using a double-tracer study design. Am J Clin Nutr 71:1545-1554

18. Leung WC, Hessel S, Meplan C, Flint J, Oberhauser V, Tourniaire F, Hesketh JE, von Lintig J, Lietz G (2009) Two common single nucleotide polymorphisms in the gene encoding \{beta\}carotene $15,15^{\prime}$-monoxygenase alter $\{$ beta $\}$-carotene metabolism in female volunteers. Faseb J 23(4):1041-1053

19. Lindqvist A, Sharvill J, Sharvill DE, Andersson S (2007) Loss-offunction mutation in carotenoid $15,15^{\prime}$-monooxygenase identified in a patient with hypercarotenemia and hypovitaminosis A. J Nutr 137:2346-2350

20. von Lintig J, Hessel S, Isken A, Kiefer C, Lampert JM, Voolstra O, Vogt K (2005) Towards a better understanding of carotenoid metabolism in animals. Biochim Biophys Acta 1740:122-131

21. Hessel S, Eichinger A, Isken A, Amengual J, Hunzelmann S, Hoeller U, Elste V, Hunziker W, Goralczyk R, Oberhauser V, von Lintig J, Wyss A (2007) CMO1 deficiency abolishes vitamin A production from beta-carotene and alters lipid metabolism in mice. J Biol Chem 282:33553-33561

22. von Lintig J, Vogt K (2000) Filling the gap in vitamin A research. Molecular identification of an enzyme cleaving beta-carotene to retinal. J Biol Chem 275:11915-11920

23. van Schothorst EM, Pagmantidis V, de Boer VC, Hesketh J, Keijer J (2007) Assessment of reducing RNA input for Agilent oligo microarrays. Anal Biochem 363:315-317

24. Rodenburg W, Keijer J, Kramer E, Vink C, van der Meer R, Bovee-Oudenhoven IM (2008) Impaired barrier function by dietary fructo-oligosaccharides (FOS) in rats is accompanied by increased colonic mitochondrial gene expression. BMC Genomics 9:144

25. Wettenhall JM, Smyth GK (2004) limmaGUI: a graphical user interface for linear modeling of microarray data. Bioinformatics 20:3705-3706

26. Pellis L, Franssen-van Hal NL, Burema J, Keijer J (2003) The intraclass correlation coefficient applied for evaluation of data correction, labeling methods, and rectal biopsy sampling in DNA microarray experiments. Physiol Genomics 16:99-106

27. Lee HK, Braynen W, Keshav K, Pavlidis P (2005) ErmineJ: tool for functional analysis of gene expression data sets. BMC Bioinformatics 6:269

28. de Boer VC, van Schothorst EM, Dihal AA, van der Woude H, Arts IC, Rietjens IM, Hollman PC, Keijer J (2006) Chronic quercetin exposure affects fatty acid catabolism in rat lung. Cell Mol Life Sci 63:2847-2858

29. Dao CT, Luo JK, Zhang DE (2006) Retinoic acid-induced protein ISGylation is dependent on interferon signal transduction. Blood Cells Mol Dis 36:406-413

30. Stamme C, Bundschuh DS, Hartung T, Gebert U, Wollin L, Nusing R, Wendel A, Uhlig S (1999) Temporal sequence of pulmonary and systemic inflammatory responses to graded polymicrobial peritonitis in mice. Infect Immun 67:5642-5650

31. Baybutt RC, Molteni A (2007) Vitamin A and emphysema. Vitam Horm 75:385-401

32. Ross AC (2003) Retinoid production and catabolism: role of diet in regulating retinol esterification and retinoic acid oxidation. J Nutr 133:291S-296S
33. Duester G (2000) Families of retinoid dehydrogenases regulating vitamin A function: production of visual pigment and retinoic acid. Eur J Biochem 267:4315-4324

34. Baybutt RC, Hu L, Molteni A (2000) Vitamin A deficiency injures lung and liver parenchyma and impairs function of rat type II pneumocytes. J Nutr 130:1159-1165

35. Iwata M, Eshima Y, Kagechika H (2003) Retinoic acids exert direct effects on T cells to suppress Th1 development and enhance Th2 development via retinoic acid receptors. Int Immunol 15:10171025

36. Mucida D, Park Y, Kim G, Turovskaya O, Scott I, Kronenberg M, Cheroutre H (2007) Reciprocal TH17 and regulatory T cell differentiation mediated by retinoic acid. Science 317:256-260

37. Gianni M, Terao M, Fortino I, LiCalzi M, Viggiano V, Barbui T, Rambaldi A, Garattini E (1997) Stat1 is induced and activated by all-trans retinoic acid in acute promyelocytic leukemia cells. Blood 89:1001-1012

38. Shang Y, Baumrucker CR, Green MH (1999) The induction and activation of STAT1 by all-trans-retinoic acid are mediated by RAR beta signaling pathways in breast cancer cells. Oncogene 18:6725-6732

39. Yang ZN, Davis GJ, Hurley TD, Stone CL, Li TK, Bosron WF (1994) Catalytic efficiency of human alcohol dehydrogenases for retinol oxidation and retinal reduction. Alcohol Clin Exp Res 18:587-591

40. Matsumoto M, Yokoyama H, Suzuki H, Shiraishi-Yokoyama H, Hibi T (2005) Retinoic acid formation from retinol in the human gastric mucosa: role of class IV alcohol dehydrogenase and its relevance to morphological changes. Am J Physiol Gastrointest Liver Physiol 289:G429-G433

41. Deltour L, Foglio MH, Duester G (1999) Impaired retinol utilization in Adh4 alcohol dehydrogenase mutant mice. Dev Genet 25:1-10

42. Kiefer C, Hessel S, Lampert JM, Vogt K, Lederer MO, Breithaupt DE, von Lintig J (2001) Identification and characterization of a mammalian enzyme catalyzing the asymmetric oxidative cleavage of provitamin A. J Biol Chem 276:14110-14116

43. Wang XD, Russell RM, Liu C, Stickel F, Smith DE, Krinsky NI (1996) Beta-oxidation in rabbit liver in vitro and in the perfused ferret liver contributes to retinoic acid biosynthesis from betaapocarotenoic acids. J Biol Chem 271:26490-26498

44. Thatcher JE, Isoherranen N (2009) The role of CYP26 enzymes in retinoic acid clearance. Expert Opin Drug Metab Toxicol 5:875-886

45. White JA, Beckett-Jones B, Guo YD, Dilworth FJ, Bonasoro J, Jones G, Petkovich M (1997) cDNA cloning of human retinoic acid-metabolizing enzyme (hP450RAI) identifies a novel family of cytochromes P450. J Biol Chem 272:18538-18541

46. Kawaguchi R, Yu J, Honda J, Hu J, Whitelegge J, Ping P, Wiita P, Bok D, Sun H (2007) A membrane receptor for retinol-binding protein mediates cellular uptake of vitamin A. Science 315:820-825

47. Thurnham DI, Northrop-Clewes CA (1999) Optimal nutrition: vitamin A and the carotenoids. Proc Nutr Soc 58:449-457

48. O'Byrne SM, Wongsiriroj N, Libien J, Vogel S, Goldberg IJ, Baehr W, Palczewski K, Blaner WS (2005) Retinoid absorption and storage is impaired in mice lacking lecithin: retinol acyltransferase (LRAT). J Biol Chem 280:35647-35657

49. Biesalski HK, Nohr D (2004) New aspects in vitamin a metabolism: the role of retinyl esters as systemic and local sources for retinol in mucous epithelia. J Nutr 134:3453S-3457S

50. KuoLee R, Zhao X, Austin J, Harris G, Conlan JW, Chen W (2007) Mouse model of oral infection with virulent type A Francisella tularensis. Infect Immun 75:1651-1660

51. Brody JS, Spira A (2006) State of the art. Chronic obstructive pulmonary disease, inflammation, and lung cancer. Proc Am Thorac Soc 3:535-537 
52. Pereg D, Lishner M (2005) Non-steroidal anti-inflammatory drugs for the prevention and treatment of cancer. J Intern Med 258:115-123

53. Schwartz AG, Prysak GM, Bock CH, Cote ML (2007) The molecular epidemiology of lung cancer. Carcinogenesis 28:507518
54. Thun MJ, Henley SJ, Patrono C (2002) Nonsteroidal antiinflammatory drugs as anticancer agents: mechanistic, pharmacologic, and clinical issues. J Natl Cancer Inst 94:252-266

55. Harvey BG, Heguy A, Leopold PL, Carolan BJ, Ferris B, Crystal RG (2007) Modification of gene expression of the small airway epithelium in response to cigarette smoking. J Mol Med 85:39-53 